\title{
Neospora spp. antibodies in horses from two geographical regions of the state of Santa Catarina, Brazil
}

Anticorpos contra Neospora spp. em equinos de duas regióes geográficas do Estado de Santa Catarina, Brasil

Anderson Barbosa de Moura' ${ }^{1 *}$; Márcio Orides da Silva ${ }^{1}$; Juliana Antunes Farias ${ }^{1}$; Achilles Vieira-Neto'; Antonio Pereira de Souza ${ }^{1}$; Amélia Aparecida Sartor ${ }^{1}$; Joandes Henrique Fonteque ${ }^{1}$; Silvério Bunn ${ }^{1}$ ${ }^{1}$ Centro de Ciências Agroveterinárias - CAV, Universidade do Estado de Santa Catarina - UDESC, Lages, SC, Brasil

Received March 20, 2013

Accepted September 16, 2013

\begin{abstract}
The aims of this study were to determine occurrences of Neospora spp. IgG antibodies in horses from two geographical regions of the state of Santa Catarina, southern Brazil, and identify risk factors for infection. Analyses were performed on 615 samples using the immunofluorescent antibody test (IFAT $\geq 1: 50)$. Out of the 615 samples, 25 (4.1\%) were positive for Neospora spp. The titers for Neospora spp. were distributed as follows: 1:50 (13), 1:100 (eight), 1:200 (three) and 1:400 (one). Out of the 311 samples taken in the mountain region, eight were positive (2.6\%). Among the samples from the coastal region (304), 17 had Neospora spp. antibodies, thus indicating occurrence of 5.6\%. Although no statistically significant difference was observed $(\mathrm{P}=0.06704)$, the prevalence among animals of the coast was 2.2 times higher than that of the mountain region. Contact with dogs and/or cattle $(P=0.007596)$ were identified as risk factor for Neospora spp. infection.
\end{abstract}

Keywords: Neospora spp., equines, IFAT, epidemiology.

\section{Resumo}

O presente estudo objetivou determinar a ocorrência de anticorpos anti-Neospora spp. em equinos das regióes serrana e litorânea de Santa Catarina e identificar possíveis fatores de risco para a infecção. Foram analisadas 615 amostras por meio da reação de imunofluorescência indireta (RIFI $\geq 1: 50)$. Das 615 amostras, 25 (4,1\%) foram positivas para Neospora spp. A recíproca dos títulos de anticorpos anti-Neospora spp. nos equinos foi assim distribuída: 1:50 (13), 1:100 (oito), 1:200 (três) e 1:400 (um). Das 311 amostras da Serra Catarinense, oito foram positivas (2,6\%). Das amostras da Regiâo Litorânea (304), 17 apresentaram anticorpos anti-Neospora spp., indicando uma prevalência de $5,6 \%$. Não foi observada diferença estatística significante $(\mathrm{P}=0,06704)$ entre as soroprevalências para Neospora spp. em equinos das diferentes regióes, porém os animais do litoral de Santa Catarina apresentaram prevalência 2,2 vezes maior que aqueles da regiáo serrana. $\mathrm{O}$ contato dos equinos com cáes e/ou bovinos $(\mathrm{P}=0,007596)$ foi identificado como fator de risco para infecçáo por Neospora spp.

Palavras-chaves: Neospora spp., equinos, RIFI, epidemiologia.

\section{Introduction}

Neosporosis is a disease that affects cattle (BAAR et al., 1991), dogs (DUBEY et al., 1988a), sheep (DUBEY et al., 1990), goats (DUBEY et al., 1992), deer (WOODS et al., 1994), buffalos (RODRIGUES et al., 2004) and horses (LINDSAY et al., 1996; DAFT et al., 1997). Among horses, the disease can be caused by $N$. caninum and $N$. hughesi. The definitive host for $N$. hughesi has not yet been determined, so it remains unknown how horses are exposed to this parasite. It is also unclear whether horses can become infected with the related species $N$. caninum (HOANE et al.,

\footnotetext{
*Corresponding author: Anderson Barbosa de Moura

Centro de Ciências Agroveterinárias - CAV, Universidade do Estado de Santa

Catarina -UDESC, Av. Luís de Camōes, 2090, CEP 88520-000, Lages, SC,

Brasil

e-mail:a2abm@cav.udesc.br
}

2006). There are still uncertainties regarding the consequences of infection either by $N$. caninum or by $N$. hughesi in horses (LOCATELLI-DITTRICH et al., 2006a).

Neosporosis causes abortion, neonatal diseases and visceral and neurological dysfunction among horses. Cases of neosporosis among horses have been discovered in the United States (DUBEY; PORTERFIELD, 1990; GRAY et al., 1996; LINDSAY et al., 1996; CHEADLE et al., 2000; DUBEY et al., 2001; FINNO et al., 2007) and in France (PRONOST et al., 1999; PITEL et al., 2003; LEON et al., 2009). In Brazil, Locatelli-Dittrich et al. (2006b) and Toscan et al. (2010) suggested that vertical transmission of Neospora spp. was occurring and, in the United States, Pusterla et al. (2011) identified endogenous transplacental infection in horses. 
In a study carried out in Brazil, Dubey et al. (1999) did not detected anti-Neospora spp. antibodies among horses $(n=101)$ in three municipalities. In another survey carried out among animals in different states and regions of Brazil, seroprevalence of $2.5 \%$ was observed (HOANE et al., 2006). In the state of Paraná, seroprevalence for Neospora spp. of $30 \%$ to $47 \%$ was observed among mares and $22.2 \%$ among precolostral foals (LOCATELLIDITTRICH et al., 2006b).

Horse neosporosis still has not been sufficiently studied in Brazil. Although some seroepidemiological studies relating to horse neosporosis have already been conducted here in Brazil, the lack of reference data throughout the state of Santa Catarina was the motive for carrying out this study.

\section{Materials and Methods}

Between August 2009 and July 2011, blood samples ( $\mathrm{n}=615)$ were taken from horses in the mountain region $(n=311)$ and coastal region $(n=304)$ of the state of Santa Catarina, southern Brazil, in 59 herds. The blood samples were obtained as random convenience samples from healthy animals. The exceptions were 72 and three samples from horses for which there were records of problems of a reproductive or neurological nature, respectively, within the preceding 12 months, although these animals were seen to be healthy at the time of sample collection. Information on the animals was obtained by means of an epidemiological questionnaire (management, frequency and type of reproductive disorders in the last 12 months, type of diet and contact with dogs and other animals). The data were entered into tables and were analyzed by means of the Fisher's exact and chi-square tests (P $\leq$ 0.05) (R Development Core Team, 2009), in order to correlate the results with the risk factors analyzed.

Tachyzoites of the NC1 strain of $N$. caninum were used as antigens (DUBEY et al., 1988b) in order to perform the immunofluorescent antibody test (IFAT) as described by Conrad et al. (1993). Serum samples were screened at 1:50 (DUBEY et al., 1999; BJÖRKMAN; UGGLA, 1999) and positive samples were tested at dilutions ranging from 1:100 to 1:400. Positive and negative serum controls were used in comparisons with all reactions.

This research project was approved by the Ethics Committee on Animal Experiments of CAV/UDESC (Protocol 1.05.09) and by the Ethics Committee on Research Involving Human Beings (Protocol 73/09 of Aug 10, 2009).

\section{Results and Discussion}

Out of 615 samples, 25 (4.1\%) were positive for Neospora spp. The reciprocity of antibody titers among the horses was 1:50 (thirteen), 1:100 (eight), 1:200 (three) and 1:400 (one). Out of the 311 samples from the mountain region, eight samples were found to be positive $(2.6 \%)$. Among the animals from the coastal region (304), 17 had antibodies against Neospora spp., thus indicating an occurrence of 5.6\%. Villalobos et al. (2006) used IFAT (1:50) to investigate antibodies against Neospora spp. among horses in the state of São Paulo. Both healthy animals and mares with reproductive problems were evaluated, and the results showed that $5.8 \%$ of the healthy horses were positive, similarly to what was observed in the present study.

The antigens that are common to both species of Neospora have demonstrated cross-reactions (MARSH et al., 1996, 1998; DUBEY et al., 2001; PACKHAM et al., 2002; GONDIM et al., 2009). Animals with $N$. hughesi infection also demonstrated antibodies when the antigen was $N$. caninum, and therefore the titers were fewer (PACKHAM et al., 2002). A distinction between $N$. caninum and $N$. hughesi can only be made by means of molecular characteristics (HOANE et al., 2005). In this respect, the current results cannot be focused specifically on either of the species of Neospora spp. that affect horses.

In the present study, the titer 1:50 represented 52\% (13/25) of the seropositive samples, thus suggesting that there was chronic infection, compatible with healthy animals. Ratios of 1:50 and 1:100, in the immunofluorescent antibody test (IFAT), are considered to be positive, and use of the 1:50 ratio can increase the sensitivity of the diagnosis (McDOLE; GAY, 2002; VARDELEON et al., 2001).

Studies on the seroprevalence of Neospora spp. in horses in Brazil have presented diverse results, ranging from $0 \%$ (DUBEY et al., 1999, using the agglutination test, 1:40) to $47 \%$ (LOCATELLIDITTRICH et al., 2006b, using IFAT, 1:50). The latter, higher seroprevalence, which was found in the state of Paraná, could be attributable to different management conditions and/or geographical position, or exposure to parasites.

The results from this study are the first to detect Neospora spp. antibodies in horses in the state of Santa Catarina. Hoane et al. (2006), evaluated 961 horse serum samples from 10 Brazilian states (São Paulo, Minas Gerais, Paraná, Santa Catarina, Rio Grande do Sul, Bahia, Rondônia, Mato Grosso, Mato Grosso de Sul and Goiás) in order to detect NhSAG1 antigen (ELISA), and 2.5\% (24/961) were found to be seropositive for Neospora spp. Out of the 24 horses in that study that were from the state of Santa Catarina, none of them presented antibodies against Neospora spp.

Most studies do not reflect a real prevalence, since the samples is not always statistically determined. In addition, the fluctuation of Neospora spp. antibody levels observed in pregnant mares (HOFFMANN-KORMANN et al., 2008) may occur due to individual or hormonal variations. This also resembles cases of recent seroconversion (immune window), which gives rise to difficulty in comparing results. Furthermore, maternal antibodies can cause false-positive results for up to three to four months (DUARTE et al., 2004) or up to 10 months of age among the foals (TOSCAN et al., 2010), since transfer can occur (PUSTERLA et al., 2011). In the present study, 15 animals were younger than 12 months and, of these, only one had antibodies against Neospora spp. (Table 1).

A difference in seroprevalence for Neospora spp. was observed in the present study between horses from different regions. Although not statistically significant $(\mathrm{P}=0.06704)$, the animals from Santa Catarina's coastal region presented occurrence that was 2.2 times higher than was seen among the horses from the mountain region (Table 1$)$. The odds ratio observed (0.45), less than one, indicates that the animals of the Santa Catarina mountains had lower occurrence of antibodies against Neospora spp. compared with animals from the coastal region, but without statistical 
Table 1. Frequency of positive equine (IFAT, $\geq 1: 50$ ) for Neospora spp. from the Mountain and Coastal regions, Santa Catarina State, Brazil, for analyzed variable and total 2012 .

\begin{tabular}{|c|c|c|c|c|c|c|c|c|}
\hline \multirow{2}{*}{\multicolumn{2}{|c|}{ Variables }} & \multicolumn{2}{|c|}{ Animals } & \multicolumn{2}{|c|}{ Positive $^{1}$} & \multicolumn{2}{|c|}{ Positive $^{2}$} & \multirow[b]{2}{*}{$\mathbf{p}$} \\
\hline & & $\mathbf{n}$ & $\%$ & $\mathbf{n}$ & $\%$ & $\mathbf{n}$ & $\%$ & \\
\hline \multirow{2}{*}{ Region } & Mountain & 311 & 50.6 & 8 & 2.6 & 8 & 32.0 & 0.0670 \\
\hline & Coastal & 304 & 49.4 & 17 & 5.6 & 17 & 68.0 & \\
\hline \multirow[t]{2}{*}{ Sex } & Male & 270 & 43.9 & 10 & 3.7 & 10 & 40.0 & 0.8376 \\
\hline & Female & 345 & 56.1 & 15 & 4.3 & 15 & 60.0 & \\
\hline \multirow{2}{*}{ Breed } & Mixed & 166 & 27.0 & 2 & 1.2 & 2 & 8.0 & 0.0356 \\
\hline & Pure & 449 & 73.0 & 23 & 5.1 & 23 & 92.0 & \\
\hline \multirow[t]{5}{*}{ Age } & $<6$ months & 04 & 0.7 & 0 & 0.0 & 0 & 0.0 & 0.4861 \\
\hline & 6-12 months & 11 & 1.8 & 1 & 9.1 & 1 & 4.0 & \\
\hline & $1-5$ years & 197 & 32.0 & 10 & 5.1 & 10 & 40.0 & \\
\hline & $6-10$ years & 227 & 36.9 & 9 & 4.0 & 9 & 36.0 & \\
\hline & $>10$ years & 176 & 28.6 & 5 & 2.8 & 5 & 20.0 & \\
\hline \multirow[t]{10}{*}{ Contact with animals } & Dog & 130 & 21.2 & 03 & 2.3 & 03 & 12.0 & 0.0075 \\
\hline & Cat & 07 & 1.1 & 00 & - & 00 & - & \\
\hline & Dog and Cat & 90 & 14.6 & 01 & 1.1 & 01 & 4.0 & \\
\hline & Dog and Bovine & 184 & 29.9 & 12 & 6.5 & 12 & 48.0 & \\
\hline & Dog, Cat and Bovine & 167 & 27.2 & 04 & 2.4 & 04 & 16.0 & \\
\hline & Dog and Pig & 02 & 0.4 & 00 & - & 00 & - & \\
\hline & Bovine & 13 & 2.1 & 04 & 30.8 & 04 & 16.0 & \\
\hline & Equine & 07 & 1.1 & 00 & - & 00 & - & \\
\hline & Dog and Chicken & 05 & 0.8 & 00 & - & 00 & - & \\
\hline & No Contact & 10 & 1.6 & 01 & 10.0 & 01 & 4.0 & \\
\hline \multirow[t]{8}{*}{ Reproductive Disorders } & Abortion & 21 & 3.4 & 0 & - & 0 & - & 0.9372 \\
\hline & Stillborn & 01 & 0.2 & 0 & - & 0 & - & \\
\hline & Mummified & 0 & - & 0 & - & 0 & - & \\
\hline & Return Season & 39 & 6.3 & 01 & 2.6 & 01 & 4.0 & \\
\hline & No Disorders & 543 & 88.2 & 24 & 4.4 & 24 & 96.0 & \\
\hline & Abortion+Return Season & 09 & 1.5 & 0 & - & 0 & - & \\
\hline & Endometritis & 01 & 0.2 & 0 & - & 0 & - & \\
\hline & $\begin{array}{l}\text { Abortion + Return Sea- } \\
\text { son + Stillborn }\end{array}$ & 01 & 0.2 & 0 & - & 0 & - & \\
\hline \multirow[t]{2}{*}{ Neurologic Disorders } & Yes & 03 & 0.5 & 0 & - & 0 & 0 & 1.0 \\
\hline & No & 612 & 99.5 & 25 & 4.1 & 25 & 100 & \\
\hline Total & & 615 & 100 & 25 & - & 25 & 100 & \\
\hline
\end{tabular}

Positive $1=$ Relation among the positive animals within a category and the total of animals of its category. Positive $2=$ Relation among the positive animals within a category and the total of positive animals. $\mathrm{p}=$ descriptive level of the Fischer exact's test.

difference, since the confidence interval $(95 \% \mathrm{CI}=0.16-1.11)$ contains the value 1.0. It is possible that the animals that live in the coastal region have a higher chance of contact with infectious forms (sporulated oocysts of Neospora spp.), which are common in warmer and humid environments. High temperatures can cause rapid sporulation of oocysts (DUBEY et al., 2007). Wouda et al. (1999) observed that abortion epidemics among dairy cows usually occurred in the hot and humid summer. Furthermore, Abo-Shehada and Abu-Halaweh (2010) identified that cold climates can reduce the seropositivity for Neospora spp. Another explanation for this could be that high average temperatures and high humidity stimulate the growth of fungi. Mycotoxins are suspected of being the cause of immunosuppression among cattle, which can cause an upsurge of latent infection due to $N$. caninum (DUBEY et al., 2007). Although these studies were carried out on cattle, their conclusions can be used to explain the results relating to the environment that were obtained in the present study.

An analysis on the risk factors found that horses belonging to a defined breed ( $\mathrm{P}=0.03568)$ demonstrated higher seropositivity. Among the horses that were positive for neosporosis, 92\% (23/25) demonstrated a defined breed pattern. However, 73\% (449/615) of the total number of animals evaluated were identified as animals belonging a breed (Table 1), thus suggesting that the higher occurrence among these animals might have resulted from the sampling, as indicated by the observed OR (0.23), less than 1 . In a study on 91 cart horses (no defined breed) and 123 Crioula breed horses in Rio Grande do Sul, Toscan et al. (2011) found that there was high seropositivity in both groups (15.4\% and $16.3 \%$, respectively), and no difference between the distinct populations was observed. However, in Santa Maria, Rio Grande do Sul, in 
traction horses (no pure breed), Sangioni et al. (2011) also found high seropositivity (15.4\%) by means of IFAT (1:50).

Close contact of horses with dogs and/or cattle presented a association $(\mathrm{P}=0.007596)$ with Neospora spp. antibodies. The observed odds ratio (2.24), greater than 1.0, indicates that the group of animals that have contact with cattle and/or dogs showed higher occurrence of antibodies against Neospora spp. Among all the positive horses, 96\% (24/25) had been in contact with dogs and/or cattle, which are the most important species in the biological cycle of $N$. caninum (DUBEY; SCHARES, 2011). This demonstrates the importance of these species in introducing and/ or maintaining infection on the farm, and perhaps in relation to its spread to horses.

The additional features that were analyzed (gender, age and reproductive and neurological disorders) did not revealed any association with occurrences of Neospora spp. antibodies among the horses in the current experiment.

\section{Conclusion}

The occurrence of Neospora spp. antibodies among analyzed horses was low and the contact with dog and/or cattle is a risk factor for infection these animals.

\section{References}

Abo-Shehada MN, Abu-Halaweh MM. Flock-level seroprevalence of, and risk factors for, Neospora caninum among sheep and goats in northern Jordan. Prev Vet Med 2010; 93(1): 25-32. PMid:19923025. http://dx.doi. org/10.1016/j.prevetmed.2009.08.004

Baar BC, Conrad PA, Dubey JP, Anderson ML. Neosporalike encephalomyelitis in a calf: pathology, ultrastructure and immunoreactivity. J Vet Diagn Invest 1991; 3(1): 39-46. http://dx.doi. org/10.1177/104063879100300109

Björkman C, Uggla A. Serological diagnosis of Neospora caninum infection. Int J Parasitol 1999; 29(10): 1497-1507. http://dx.doi. org/10.1016/S0020-7519(99)00115-0

Cheadle MA, Lindsay DS, Rowe S, Dykstra CC, Williams MA, Spencer JA, et al. Prevalence of antibodies to Neospora sp. in horses from Alabama and characterization of an isolate recovered from a naturally infected horse. Int J Parasitol 1999; 29(10): 1537-1543. See erratum in: Int J Parasitol 2000; 30(5): 677. http://dx.doi.org/10.1016/S00207519(00)00044-8

Conrad PA, Baar BC, Sverlow KW, Anderson ML, Daft B, Kinde H, et al. In vitro isolation and characterization of a Neospora sp. from aborted bovine foetuses. Parasitology 1993; 106(Pt3): 239-249. PMid:8488061. http://dx.doi.org/10.1017/S0031182000075065

Daft BM, Baar BC, Collins N, Sverlow K. Neospora encephalomyelitis and polyradiculoneuritis in an aged mare with Cushing's disease. Equine Vet J 1997; 29(3): 240-243. PMid:9234020. http://dx.doi. org/10.1111/j.2042-3306.1997.tb01678.x

Duarte PC, Conrad PA, Wilson WD, Ferraro GL, Packham AE, Bowers-Lepore J, et al. Risk of postnatal exposure to Sarcocystis neurona and Neospora hughesi in horses. Am J Vet Res 2004; 65(8): 1047-1052. PMid:15334837. http://dx.doi.org/10.2460/ajvr.2004.65.1047
Dubey JP, Porterfield M.L. Neospora caninum (Apicomplexa) in an aborted equine fetus. J Parasitol 1990; 76(5): 732-734. http://dx.doi. org/10.2307/3282991

Dubey JP, Schares G. Neosporosis in animals - The last five years. Vet Parasitol 2011; 180 (1-2): 90-108. PMid:21704458. http://dx.doi. org/10.1016/j.vetpar.2011.05.031

Dubey JP, Carpenter JL, Speer CA, Topper MJ, Uggla A. Newly recognized fatal protozoan disease of dogs. J Am Vet Med Assoc 1988a; 192(9): 12691285. PMid:3391851.

Dubey JP, Hatel AL, Lindsay D, Topper MJ. Neonatal Neospora caninum infection in dogs: Isolation of the causative agent and experimental transmission. J Am Vet Med Assoc 1988b; 193(10): 1259-1263. PMid:3144521.

Dubey JP, Hartley WJ, Lindsay DS, Topper MJ. Fatal congenital Neospora caninum infection in a lamb. J Parasitol 1990; 76(1): 127-130. PMid:2299518. http://dx.doi.org/10.2307/3282640

Dubey JP, Acland HM, Hamir AN. Neospora caninum (Apicomplexa) in a stillborn goat. J Parasitol 1992; 78(3): 532-534. PMid:1597802. http://dx.doi.org/10.2307/3283661

Dubey JP, Kerber CE, Granstrom DE. Serologic prevalence of Sarcocystis neurona, Toxoplasma gondii, and Neospora caninum in horses in Brazil. $J$ Am Vet Med Assoc 1999; 215(7): 970-972. PMid:10511862.

Dubey JP, Liddel S, Mattson D, Speert CA, Howe DK, Jenkins MC. Characterization of the Oregon isolate of Neospora hughesi from a horse. J Parasitol 2001; 87(2): 345-353. PMid:11318565.

Dubey JP, Schares G, Ortega-Mora LM. Epidemiology and Control of Neosporosis and Neospora caninum. Clin Microbiol Rev 2007; 20(2): $323-$ 367. PMid:17428888 PMCid:PMC1865591. http://dx.doi.org/10.1128/ CMR.00031-06

Finno CJ, Aleman M, Pusterla N. Equine protozoal myeloencephalitis associated with neosporosis in 3 horses. J Vet Intern Med 2007; 21(6): 1405 1408. PMid:18196754. http://dx.doi.org/10.1111/j.1939-1676.2007. tb01966.x

Gondim LFP, Lindsay DS, McAllister MM. Canine and bovine Neospora caninum control sera examined for cross-reactivity using Neospora caninum and Neospora hughesi indirect fluorescent antibody tests. J Parasitol 2009; 95(1): 86-88. PMid:18613752. http://dx.doi. org/10.1645/GE-1710.1

Gray ML, Harmon BG, Sales L, Dubey JP. Visceral neosporosis in a $10-$ year-old horse. J Vet Diagn Invest 1996; 8(1): 130-133. PMid:9026072. http://dx.doi.org/10.1177/104063879600800125

Hoane JS, Yeargan MR, Stamper S, Saville WJ, Morrow JK, Lindsay DS, et al. Recombinant NhSAG1 ELISA: a sensitive and specific assay for detecting antibodies against Neospora hughesi in equine serum. J Parasitol 2005; 91(2): 446-452. PMid:15986623. http://dx.doi. org/10.1645/GE-395R

Hoane JS, Gennari SM, Dubey JP, Ribeiro MG, Borges AS, Yai LEO, et al. Prevalence of Sarcocystis neurona and Neospora spp. infection in horses from Brazil based on presence of serum antibodies to parasite surface antigen. Vet Parasitol 2006; 136(2): 155-159. PMid:16310955. http://dx.doi.org/10.1016/j.vetpar.2005.10.023

Hoffmann-Kormann DCS, Locatelli-Dittrich R, Richartz RRTB, Antunes J, Dittrich JR, Patrício LFL. Soroprevalência e cinética mensal de anticorpos anti-Neospora sp. em éguas gestantes. Rev Bras Parasitol Vet 2008; 17(S1): 335-338. 
Leon A, Laugier C, Pronost S, Portier G. Infectious abortion in mares: characterisation of new pathogenic agents. Pratic Vet Equine 2009; 41(164): 33-36.

Lindsay DS, Steinberg H, Dubielzig RR, Semrad SD, Konkle DM, Miller PE, et al. Central nervous system neosporosis in a foal. $J$ Vet Diagn Invest 1996; 8(4): 507-510. PMid:8953546. http://dx.doi. org/10.1177/104063879600800424

Locatelli-Dittrich R, Hoffmann DCS, Dittrich JR. Neosporose eqüina - Revisão. Arch Vet Sci 2006a; 11(3): 1-10.

Locatelli-Dittrich R, Dittrich JR, Richartz RRTB, Gasino-Joineau ME, Antunes J, Pinckney RD, et al. Investigation of Neospora sp. and Toxoplasma gondii antibodies in mares and in precolostral foals from Parana state, Southern Brazil. Vet Parasitol 2006b; 135(3-4): 215-221. PMid:16289863. http://dx.doi.org/10.1016/j.vetpar.2005.10.010

Marsh AE, Baar BC, Madigan J, Lakritz J, Nordhausen R, Conrad PA. Neosporosis as a cause of equine protozoal myeloencephalitis. $J$ Am Vet Med Assoc 1996; 209(11): 1907-1913. PMid:8944807.

Marsh AE, Baar BC, Packham AE, Conrad PA. Description of a new Neospora species (Protozoa: Apicomplexa: Sarcocystidae). J Parasitol 1998; 84(5): 983-991. PMid:9794642. http://dx.doi. org/10.2307/3284632

McDole MG, Gay JM. Seroprevalence of antibodies against Neospora caninum in diagnostic equine serum samples and their possible association with fetal loss. Vet Parasitol 2002; 105(3): 257-260. http://dx.doi. org/10.1016/S0304-4017(02)00039-0

Packham AE, Conrad PA, Wilson WD, Jeanes LV, Sverlow KW, Gardner IA, et al. Qualitative evaluation of selective tests for detection of Neospora hughesi antibodies in serum and cerebrospinal fluid of experimentally infected horses. .J Parasitol 2002; 88(6): 1239-1246. PMid:12537119.

Pitel PH, Romand S, Pronost S, Foucher N, Gargala G, Maillard K, et al. Investigation of Neospora sp. antibodies in aborted mares from Normandy, France. Vet Parasitol 2003; 118(1-2): 1-6. PMid:14651869. http://dx.doi. org/10.1016/j.vetpar.2003.10.007

Pronost S, Pitel PH, Romand S, Thulliez P, Collobert C, Fortier G. Neospora caninum: first case in France in an aborted equine fetus. Analysis and perspectives. Pratic Vet Equine 1999; 31(122): 111-114.

Pusterla N, Conrad PA, Packham AE, Mapes SM, Finno CJ, Gardner IA, et al. Endogenous transplacental transmission of Neospora hughesi in naturally infected horses. J Parasitol 2011; 97(2): 281-285. PMid:21506870. http://dx.doi.org/10.1645/GE-2657.1
R Development Core Team. R: A language and environment for statistical computing. Vienna: R Foundation for Statistical Computing; 2009. Available from: http://www.R-project.org.

Rodrigues AAR, Gennari SM, Aguiar DM, Sreekumar C, Hill DE, Miska $\mathrm{KB}$, et al. Shedding of Neospora caninum oocysts by dogs fed tissues from naturally infected water buffaloes (Bubalus bubalis) from Brazil. Vet Parasitol 2004; 124(3-4): 139-150. PMid:15381294. http://dx.doi. org/10.1016/j.vetpar.2004.07.007

Sangioni LA, Botton S de A, CargneluttI JF, Cadore GC, Cezar AS, Weiblen R, et al. Pesquisa de anticorpos anti-Neospora spp. e anti herpesvírus equino em cavalos de traçáo no município de Santa Maria, RS, Brasil. Cienc Rural2011; 41(2): 321-323. http://dx.doi.org/10.1590/ S0103-84782011000200023

Toscan G, Cadore GC, Pereira RCF, Silva GB, Cezar AS, Sangioni LA, et al. Neosporose equina: ocorrência de anticorpos anti-Neospora spp. e associação entre status sorológico de éguas e de suas crias. Pesq Vet Bras 2010; 30(8): 641-645. http://dx.doi.org/10.1590/S0100736X2010000800006

Toscan G, Vogel FSF, Cadore GC, Cezar AS, Sangioni LA, Pereira RCF, et al. Occurrence of antibodies anti-Neospora spp. in cart horses and Crioula breed horses from Rio Grande do Sul state. Arq Bras Med Vet Zootec 2011; 63(1): 258-261. http://dx.doi.org/10.1590/S010209352011000100038

Vardeleon D, Marsh AE, Thorne JG, Loch W, Young R, Johnson PJ. Prevalence of Neospora hughesi and Sarcocystis neurona antibodies in horses from various geographical locations. Vet Parasitol 2001; 95(2-4): 273-282. http://dx.doi.org/10.1016/S0304-4017(00)00393-9

Villalobos EMC, Ueno TEH, Souza SLPD, Cunha EMS, Lara MCCDSH, Gennari SM, et al. Association between the presence of serum antibodies against Neospora spp. and fetal loss in equines. Vet Parasitol 2006; 142(3): 372-375. PMid:16962708. http://dx.doi. org/10.1016/j.vetpar.2006.07.016

Woods LW, Anderson ML, Swift PK, Sverlow KW. Systemic neosporosis in a California black-tailed deer (Odocoileus hemionus columbianus). J Vet Diagn Invest 1994; 6(4): 508-510. PMid:7858040. http://dx.doi. org/10.1177/104063879400600425

Wouda W, Bartels CJM, Moen AR. Characteristics of Neospora caninum-associated abortion storms in dairy herds in the Netherlands (1995 to 1997). Theriogenology 1999; 52(2): 233-245. http://dx.doi. org/10.1016/S0093-691X(99)00125-9 